\title{
ГЕНДЕРНІ ОСОБЛИВОСТІ ВПЛИВУ ГІПЕРГОМОЦИСТЕЇНЕМІЇ НА МЕТАБОЛІЗМ СІРКОВМІСНИХ АМІНОКИСЛОТ ТА ГІДРОГЕН СУЛЬФІДУ В ПЕЧІНЦІ
}

Вступ. Порушення обміну сірковмісних амінокислот є визнаними метаболічними фракторами ризику кардіоваскулярної патології. Однак залишається нез'ясованим питання стосовно їх причетності до фрормування стать-специфрічної патології серцево-судинної системи.

Мета дослідження-вивчити вплив тривалої тіолактонової гіпергомоцистеїнемії на вміст сірковмісних метаболітів у крові та активність ензимів обміну гомоцистеїну, цистеїну і гідроген сульфріду в печінці щурів обох статей.

Методи дослідження. Досліди проведено на 40 білих лабораторних щурах обох статей масою 220-280 г. Модель тривалої гіпергомоцистеїнемії створювали шляхом введення тіолактону $D, L$-гомоцистеїну інтрагастрально в дозі 100 мг/кг маси на 1 \% розчині крохмалю 1 раз на добу протягом 28 діб. У роботі визначали вміст гомоцистеїну, цистеїну та гідроген сульфріду в сироватці крові, а також активність ензимів цистатіонін- $y$-ліази, цистатіонін- $\beta$-синтази, цистеїнамінотрансорерази, метіонінаденозилтрансферази, цистеїндіоксигенази та у-глутамілцистеїнлігази в печінці.

Результати й обговорення. Гіпергомоцистеїнемія ініціювала стать-специфрічні зміни вмісту сірковмісних метаболітів у сироватці крові щурів: зростання вмісту гомоцистеїну й цистеїну та зниження рівня гідроген сульфріду становили, відповідно, 111; 59,2 та 59,4 \% у самців, 82,4; 38,0 і 47,5 \% у самок $(p<0,05)$ порівняно з контролем. За умов гіпергомоцистеїнемії в самців відмічали більш виразне зниження в печінці активності ензимів реметилування і транссульфування гомоцистеїну (на 20,5-24,8 \% у самців, на 13,4-15,4 \% у самок, р<0,05), ензимів деградації цистеїну в окисному та кон'югаційному шляхах (на 21,1-22,0 \% у самців, на 13,4-15,3 \% у самок, p<0,05) та $\mathrm{H}_{2} \mathrm{~S}$-продукуючих ензимів (на 20,6-25,9 \% у самців, на 13,5-17,5\% у самок, р<0,05) порівняно з контролем.

Висновки. Показано, що тривале введення тіолактону гомоцистеїну супроводжується зростанням вмісту гомоцистеїну, цистеїну та зменшенням рівня гідроген сульфріду в крові особин обох статей, однак більш істотні зміни відмічають у самців. Поряд із цим реєструють стать-специфрічні зміни метаболізму сірковмісних сполук у печінці: в самців відзначають достовірно більше зниження активності ензимів реметилування і транссульфування гомоцистеїну, ензимів деградації цистеїну та синтезу гідроген сульфріду в печінці порівняно із самками щурів.

КЛЮЧОВІ СЛОВА: гомоцистеїн; цистеїн; гідроген сульфрід; кров; печінка; ензими.

ВСТУП. Порушення обміну сірковмісних амінокислот, які супроводжуються зростанням у крові вмісту гомоцистеїну (гіпергомоцистеїнемія - ГГЦ), цистеїну (гіперцистеїнемія) та фрормуванням десріциту гідроген сульфіду, є визнаними метаболічними фракторами ризику кардіоваскулярної патології $[1,2]$. Відомо, що важливу роль у розвитку і поширеності патології серця та судин відіграє стать. Найбільш вразливими щодо серцево-судинних захворювань є жінки старшого і похилого віку, а втім, за прогнозами ВОО3, у найближчому майбутньому кожна друга жінка світу буде старшою 45 років [3]. Показано, що

(с) А. В. Мельник, Н. В. Заічко, 2017. поширеність ішемічної хвороби серця та артеріальної гіпертензії зростає з віком і до 55 років переважає в чоловічій популяції, а після - в жіночій [4]. Однак залишається нез'ясованим питання стосовно причетності порушень обміну сірковмісних амінокислот до фрормування стать-специфічної патології серцево-судинної системи.

Мета дослідження - оцінити вплив тіолактонової гіпергомоцистеїнемії на вміст гомоцистеїну, цистеїну та гідроген сульфріду в сироватці крові, активність ензимів метаболізму сірковмісних амінокислот у печінці щурів залежно від статі. 
МЕТОДИ ДОСЛІДЖЕННЯ. Досліди проведено на 40 білих лабораторних щурах обох статей масою 220-280 г. Тварини перебували в стандартних умовах з природним світловим режимом день/ніч, воду і корм отримували ad libitum. щурів годували напівсинтетичною крохмально-казеїновою дієтою зі збалансованим вмістом усіх макро- та мікронутрієнтів. Дослідження проведено за загальними етичними принципами експериментів на тваринах, схваленими на Першому національному конгресі України з біоетики (Київ, 2001), і відповідно до Європейської конвенції про захист хребетних тварин, що використовуються для дослідних та інших наукових цілей (Страсбург, 1986). Щурів випадковим чином поділяли на групи, по 10 особин у кожній.

Модель гіпергомоцистеїнемії створювали шляхом введення тіолактону D,L-гомоцистеїну ("Sigma", США) інтрагастрально в дозі 100 мг/кг маси на $1 \%$ розчині крохмалю 1 раз на добу протягом 28 діб [5]. Знеживлювали тварин методом декапітації під пропофоловим наркозом ("Fresenius Kabi", 60 мг/кг, внутрішньочеревно).

Активність $\mathrm{H}_{2} \mathrm{~S}$-продукуючих ензимів - цистатіонін-у-ліази (ЦГЛ, КФ 4.4.1.1), цистатіонін- $\beta$-синтази (ЦБС, КФ 4.2.1.22), цистеїнамінотранссрерази (ЦАТ, КФ 2.6.1.3) в пост'ядерному гомогенаті печінки визначали в адаптованих нами інкубаційних середовищах за приростом сульфрід-аніона [6]. Активність ЦБС оцінювали за утворенням цистатіоніну в реакції конденсації гомоцистеїну із серином [7]. Активність метіонінаденозилтранссрерази (МАТ, КФ 2.5.1.6) визначали за приростом неорганічного фоосфату в реакції метіоніну з АТФ [8]. Активність цистеїндіоксигенази (ЦДО, КФ 1.13.11.20) оцінювали за швидкістю перетворення цистеїну в цистеїнсульфінову кислоту [9]. Активність у-глутамілцистеїнлігази (у-ГЦЛ, КФ 6.3.2.2) визначали за кількістю неорганічного фроссрату, що утворювався при гідролізі АТФ під час взаємодії глутамату із цистеїном [10]. Вміст гомоцистеїну в сироватці крові визначали за допомогою набору "Homocysteine EIA" ("Axis-Shield", Англія). Рівень загального цистеїну в крові визначали за реакцією 3 нінгідриновим реактивом у кислому середови- щі після відновлення цистину в цистеїн під впливом дитіотреітолу [11]. Вміст $\mathrm{H}_{2} \mathrm{~S}$ у сироватці крові визначали за реакцією утворення тіоніну 3 використанням n-френілендіаміну [12].

Статистичну обробку результатів проводили за допомогою програми SPSS Statistica 17.0. Характер розподілу визначали за допомогою критерію Колмогорова-Смірнова. Достовірність різниці між показниками оцінювали за параметричним t-критерієм Стьюдента (при нормальному розподілі) та непараметричним U-критерієм Манна-Уїтні (при невідповідності нормальному розподілу). Вірогідними вважали дані при р<0,05.

РЕЗУЛЬТАТИЙ ОБГОВОРЕННЯ. ГіПерГОМОцистеїнемія супроводжувалася зростанням вмісту гомоцистеїну, цистеїну і зменшенням рівня гідроген сульфріду в сироватці крові самців та самок щурів. Вказані зміни більш виразними були в самців (табл. 1). Так, введення тіолактону гомоцистеїну викликало статистично достовірне підвищення рівня гомоцистеїну: в самців - у 2,1 раза $(p<0,05)$, а в самок - в 1,8 раза $(p<0,05)$ порівняно з відповідними показниками в групі контролю. Поряд із цим відмічали збільшення рівня цистеїну: в самців - на 59,2 \% ( $<<0,05)$, а в самок - на $38,0 \%(p<0,05)$ порівняно 3 контролем. Також реєстрували зменшення вмісту гідроген сульфріду в сироватці крові: у самців - на $59,4 \%(p<0,05)$, тоді як у самок - на $47,5 \%$ $(p<0,05)$ порівняно з контролем. За умов тривалої гіпергомоцистеїнемії відмічали більш виразні зміни сірковмісних метаболітів у крові: в групі контролю у самців рівень гомоцистеїну і цистеїну, відповідно, на 20,0 та 23,0 \% $(p<0,05)$ більший, а вміст гідроген сульфріду - на 23,3 \% менший, ніж у самок, тоді як у групі тварин з гіпергомоцистеїнемією ці відмінності були вірогідно вищими і становили, відповідно, 30,0; 33,2 та 59,3 \% $(p<0,05)$.

Далі ми оцінювали вплив експериментальної гіпергомоцистеїнемії на активність ензимних систем утилізації гомоцистеїну та цистеїну в печінці щурів обох статей. Встановлено, що тривале введення тіолактону гомоцистеїну супроводжувалося зменшенням швидкості утилі-

Таблиця 1 - Вплив гіпергомоцистеїнемії на активність ензимів циклу метилування гомоцистеїну в печінці щурів обох статей $(\mathrm{M} \pm \mathrm{m}, \mathrm{n}=10)$

\begin{tabular}{|c|c|c|c|c|}
\hline \multirow{2}{*}{ Група тварин } & \multirow[b]{2}{*}{ Стать } & \multicolumn{3}{|c|}{ Вміст метаболітів, мкмоль/л } \\
\hline & & гомоцистеїн & цистеїн & $\mathrm{H}_{2} \mathrm{~S}$ \\
\hline Контроль & Самці & $7,68 \pm 0,13$ & $143 \pm 2,95$ & $77,6 \pm 2,76$ \\
\hline \multirow[t]{2}{*}{ ГГЦ } & Самці & $16,2 \pm 0,52^{*}$ & $228 \pm 4,12^{*}$ & $31,5 \pm 1,10^{*}$ \\
\hline & Самки & $11,4 \pm 0,34^{* 0}$ & $152 \pm 2,87^{* 0}$ & $50,2 \pm 1,51^{* \circ}$ \\
\hline
\end{tabular}

Примітки. Тут і в таблицях 2, 3:

1. * - статистично достовірна відмінність $(p<0,05)$ відносно відповідної групи контролю.

2. ${ }^{\circ}$ - статистично достовірна відмінність $(p<0,05)$ між самцями та самками в межах групи. 
зації гомоцистеїну в реакціях реметилування і транссульфрування, а також деградації цистеїну в окисному та кон'югаційному шляхах у самців і самок. Вплив гіпергомоцистеїнемії більш істотним був саме в самців (табл. 2). Так, введення тіолактону гомоцистеїну станом на 28 добу викликало сповільнення реакції активації метіоніну з участю МАТ: у самців - на 20,5\% $\%(p<0,05)$, а в самок - на 13,4 \% $(p<0,05)$ порівняно $з$ контролем. Також зменшувалася швидкість реакції конденсації гомоцистеїну та серину з утворенням цистатіоніну з участю ЦБС: у самців - на 24,8 \% $(p<0,05)$, а в самок - на 15,4 \% $(p<0,05)$ порівняно з відповідними показниками в групі контролю. Поряд із цим зменшувалася швидкість окиснення цистеїну до цистеїнсульфрату з участю ЦДО: в самців - на 21,1 \% ( $<<0,05)$, а в самок - на $13,4 \%(p<0,05)$ порівняно 3 контролем. У групі тварин 3 гіпергомоцистеїнемією знижувалась активність реакції кон'югації цистеїну з глутаматом 3 участю у-ГЦЛ (започатковувала синтез глутатіону): в самців - на 22,0 \% (p<0,05), а в самок - на 15,9 \% $(p<0,05)$ порівняно $з$ контролем. Статеві відмінності активності ензимів утилізації гомоцистеїну та цистеїну в печінці значно посилювалися за умов модельованої патології: в групі контролю у самців активність цих ензимів була на 19,0-30,0 \% меншою $(p<0,05)$, ніж у самок, тоді як у дослідній групі-на 33,8-42,7\% $(p<0,05)$.

Тривале введення тіолактону гомоцистеїну супроводжувалося зменшенням активності $\mathrm{H}_{2} \mathrm{~S}$-продукуючих ензимів у печінці самців та самок. Слід зауважити, що більш істотне зниження синтезу гідроген сульфіду відмічали в самців (табл. 3). За умов гіпергомоцистеїнемії відзначали зменшення активності синтезу гідроген сульфріду в реакції конденсації цистеїну та гомоцистеїну з участю ЦБС у самців і самок щурів, відповідно, на 21,4 та 13,6 \% $(p<0,05)$ порівняно 3 контролем. Висока концентрація тіолактону гомоцистеїну також викликала зниження утворення гідроген сульфріду в реакції десульфрурування цистеїну з участю ЦГЛ у самців і самок щурів, відповідно, на 25,9 та 17,5 \% $(p<0,05)$ порівняно 3 контролем. Поряд із цим відмічали зменшення продукції $\mathrm{H}_{2} \mathrm{~S}$ у реакції трансамінування цистеїну $3 \alpha$-кетоглутаратом 3 участю ЦАТ у самців і самок щурів, відповідно, на 20,6 та 13,5\% $(p<0,05)$ порівняно з контролем. За умов модельованої патології значно посилювалися статеві відмінності активності $\mathrm{H}_{2} \mathrm{~S}$-продукуючих ензимів у печінці: в групі контролю активність ЦБС, ЦГЛ та ЦАТ у самців була вищою, відповідно, на 24,3; 25,6 і 26,4% (р<0,05), ніж у самок, а в дослідній групі ці відмінності становили, відповідно, 36,6; 39,7 та 37,7 \% $(p<0,05)$.

Проведені дослідження засвідчили, що гіпергомоцистеїнемія чинить стать-специсічний вплив на активність основних ензиматичних шляхів метаболізму сірковмісних амінокислот у печінці щурів та вміст сірковмісних метаболітів у крові. Встановлено, що тривале введення тіолактону гомоцистеїну самцям щурів мало вірогідно більший депримуючий вплив на активність у печінці ензимів утилізації гомоцистеїну (МАТ, ЦБС), деградації цистеїну (ЦДО, у-ГЦЛ) і синтезу гідроген сульфріду (десульфуразна активність ЦБС, ЦГЛ та ЦАТ), що супроводжувалося істотнішим зростанням вмісту гомоцистеїну, цистеїну і зменшенням рівня гідроген сульсріду в сироватці крові тварин цієї статі. За умов гіпергомоцистеїнемії значно поглиблювалися статеві відмінності активності основних ензимів метаболізму сірковмісних амінокислот у печінці щурів та вмісту сірковмісних метаболітів у крові порівняно з такими в групі контролю.

Виникає питання щодо фракторів, які визначають статеві відмінності впливу тіолактонової

Таблиця 2 - Вплив гіпергомоцистеїнемії на активність ензимів утилізації цистеїну та гомоцистеїну в печінці щурів обох статей $(\mathrm{M} \pm \mathrm{m}, \mathrm{n}=10)$

\begin{tabular}{|l|c|c|c|c|c|}
\hline \multirow{2}{*}{ Група тварин } & \multirow{2}{*}{ Стать } & \multicolumn{4}{|c|}{ Активність ензимів, нмоль/хв·мГ протеїну } \\
\cline { 3 - 6 } & & ЦДО ${ }^{1}$ & У-ГЦЛ & ЦБС & МАТ \\
\hline \multirow{2}{*}{ Контроль } & Самці & $2,29 \pm 0,07$ & $3,62 \pm 0,15$ & $14,9 \pm 0,67$ & $2,73 \pm 0,11$ \\
\cline { 2 - 6 } & Самки & $2,98 \pm 0,09^{\circ}$ & $4,49 \pm 0,19^{\circ}$ & $18,7 \pm 0,38^{\circ}$ & $3,29 \pm 011^{\circ}$ \\
\hline ГГЦ & Самці & $1,81 \pm 0,08^{\star}$ & $2,82 \pm 0,17^{*}$ & $11,2 \pm 0,33^{\star}$ & $2,17 \pm 0,09^{\star}$ \\
\cline { 2 - 6 } & Самки & $2,58 \pm 0,07^{\star \circ}$ & $3,78 \pm 0,12^{\star \circ}$ & $15,8 \pm 0,76^{\star \circ}$ & $2,85 \pm 0,16^{* \circ}$ \\
\hline
\end{tabular}

Примітка. ${ }^{1}$ - активність ензиму в мкмоль/хв·мг протеїну.

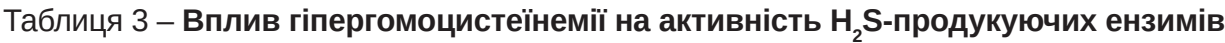
у печінці щурів обох статей $(\mathrm{M} \pm \mathrm{m}, \mathrm{n}=10)$

\begin{tabular}{|c|c|c|c|c|}
\hline Група тварин & Стать & \multicolumn{3}{|c|}{ "Десульфуразна активність ензимів, нмоль/хв·мг протеїну } \\
\hline Контроль & Самки & $3,94 \pm 0,22^{\circ}$ & $3,58 \pm 0,27^{\circ}$ & $3,24 \pm 0,18^{\circ}$ \\
\hline ГГЦ & Самки & $3,40 \pm 0,13^{\star 0}$ & $2,95 \pm 0,19 * 0$ & $2,80 \pm 0,08^{\star \circ}$ \\
\hline
\end{tabular}


гіпергомоцистеїнемії на обмін гомоцистеїну, цистеїну та гідроген сульсріду в печінці. На нашу думку, більш виразний депримуючий вплив гіпергомоцистеїнемії на активність ензимів утилізації гомоцистеїну в печінці самців до певної міри зумовлений істотно вищою активністю оксидативного стресу в особин цієї статі, адже МАТ та ЦБС $є$ редокс-чутливими ензимами $[13,14]$. В дослідженнях in vitro показано, що конкурентним інгібітором цистеїндіоксигенази (основного ензиму утилізації цистеїну) $є$ висока концентрація гомоцистеїну [15]. Тому, ймовірно, більший вміст гомоцистеїну в самців $€$ однією з причин меншої швидкості утилізації цистеїну в печінці особин цієї статі за гіпергомоцистеїнемії. Раніше ми показали, що висока концентрація цистеїну та гомоцистеїну викликає субстратне інгібування активності ензимів синтезу гідроген сульфріду в нирках щурів [6]. На нашу думку, вірогідно більший рівень цих сірковмісних амінокислот у крові самців може бути одним із фракторів меншої активності гідроген сульфрідпродукуючих ензимів у печінці самців на тлі модельованої патології. За даними літератури [16], в дорослих здорових жінок активність реакцій реметилування є вищою, ніж у чоловіків, що узгоджується з результатами наших досліджень (активність МАТ у печінці самок була вищою, ніж у самців). Ми виявили статеві відмінності активності ензимів транссульфування гомоцистеїну (ЦБС), деградації цистеїну (ЦДО, у-ГЦЛ) та утворення гідроген сульфіду (ЦГЛ, ЦБС і ЦАТ). Очевидно, вихідні відмінності активності цих ензимів у самців та самок $€$ потенційним базисом для поглиблення статевого диморфізму обміну сірковмісних амінокислот та гідроген сульфіду в печінці щурів за умов гіпергомоцистеїнемії.

Гіпергомоцистеїнемія ініціювала стать-специфрічні зміни вмісту сірковмісних метаболітів у сироватці крові щурів: зростання вмісту гомоцистеїну й цистеїну та зниження рівня гідроген сульфіду становили, відповідно, 111; 59,2 та $59,4 \%$ у самців, 82,$4 ; 38,0$ і $47,5 \%$ у самок $(p<0,05)$ порівняно з контролем.

За умов гіпергомоцистеїнемії в самців відмічали більш виразне зниження в печінці активності ензимів реметилування і транссульсрування гомоцистеїну (на 20,5-24,8 \% у самців, на 13,4-15,4 \% у самок, $p<0,05)$, ензимів деградації цистеїну в окисному та кон'югаційному шляхах (на 21,1-22,0 \% у самців, на 13,4-15,3 \% у самок, p<0,05) та $\mathrm{H}_{2} \mathrm{~S}$-продукуючих ензимів (на 20,6$25,9 \%$ у самців, на 13,5-17,5 \% у самок, $p<0,05)$ порівняно $з$ контролем.

ВИСНОВКИ. Показано, що тривале введення тіолактону гомоцистеїну супроводжується зростанням вмісту гомоцистеїну, цистеїну та зменшенням рівня гідроген сульфріду в крові особин обох статей, однак більш істотні зміни відмічають у самців. Поряд із цим реєструють стать-специсрічні зміни метаболізму сірковмісних сполук у печінці: в самців відзначають достовірно більше зниження активності ензимів реметилування і транссульфування гомоцистеїну, ензимів деградації цистеїну та синтезу гідроген сульфіду в печінці порівняно із самками щурів.

Перспективи подальших досліджень. Подальші дослідження в цьому напрямку дозволять поглибити розуміння патогенезу та шляхів корекції гендерасоційованої патології.

\section{СПИСОК ЛІТЕРАТУРИ}

1. Moat S. J. Plasma total homocysteine: instigator or indicator of cardiovascular disease? / S. J. Moat//Ann. Clin. Biochem. - 2008. - 45. - P. 345-348.

2. Wang R. Hydrogen sulfide: the third gasotransmitter in biology and medicine / R. Wang // Antioxid. Redox. Signal. - 2010. - 12, № 9. - P. 1061-1064.

3. Барна О. М. Гендерна кардіологія. Проекція на аритмії у жінок / О. М. Барна // Медицинские аспекты здоровья женщины. - 2007. - 4, № 7. - C. 14-18.

4. Sex and gender differences in myocardial hypertrophy and heart failure / V. Regitz-Zagrosek, S. OerteltPrigione, U. Seeland [et al.] // Circ. J. - 2010. - 74 (7). P. 1265-1273.

5. Homocysteine thiolactone-induced hyperhomocysteinemia does not alter concentrations of cholesterol and SREBP-2 target gene mRNAS in rats / G. I. Stangl, K. Weisse, C. Dinger [et al.] // Exp. Biol. Med. (Maywood). - 2007. - 232, № 1. - P. 81-87.

6. Мельник А. В. Активність ензимів синтезу гідроген сульсріду в нирках щурів / А. В. Мельник, О. О. Пентюк // Укр. біохім. журн. - 2009. - 81, № 4. - С. 12-22.

7. Goldstein J. L. Cystathionine synthase activity in human lymphocytes: induction by phytohemagglutinin / J. L. Goldstein, B. K. Campbell, S. M. Gartler // J. Clin. Invest. - 1972. - 51, № 4. - P. 1034-1037.

8. Chiang P. K. Activation of methionine for transmethylation. Purification of the S-adenosylmethionine synthetase of bakers' yeast and its separation into two forms / P. K. Chiang, G. L. Cantoni // J. Biol. Chem. 1977. - 252, № 13. - P. 4506-4513. 
9. Stipanuk M. H. Catabolism of cyst(e)ine by rat renal cortical tubules / M. H. Stipanuk, J. De la Rosa, L. L. Hirschberger // J. Nutr. - 1990. - 120, № 5. P. $450-458$

10. Orlowski M. Partial reaction by y-glutamylcysteine synthetase and evidence for an activated glutamate intermediate / M. Orlowski, A. Mrister // J. Biol. Chem. 1971. - 246, № 23. - P. 7095-7105.

11. Gaitonde M. K. A spectrophotometric method for direct determination of cysteine in the presence of other naturally occuring amino acid / M. K. Gaitonde // Biochem. J. - 1967. - 104, № 2. - Р. 627-633.

12. Визначення вмісту гідроген сульфіду в сироватці крові / Н. В. Заічко, Н. О. Пентюк, Л. О. Пентюк, А. В. Мельник // Вісн. наук. дослідж. - 2009. № 1. - C. 29-32.

\section{REFERENCES}

1. Moat, S.J. (2008). Plasma total homocysteine: instigator or indicator of cardiovascular disease? Ann. Clin. Biochem., 45, 345-348.

2. Wang, R. (2010). Hydrogen sulfide: the third gasotransmitter in biology and medicine. Antioxid. Redox. Signal., 12 (9), 1061-1064.

3. Barna, O.M. (2007). Henderna kardiolohiia. Proektsiia na arytmii u zhinok [Gender cardiology. Projection on arrhythmias in women]. Meditsinskie aspekty zdorovia Zhenshchiny - Medical Aspects of Women's Health, 4 (7), 14-18 [in Ukrainian].

4. Regitz-Zagrosek, V., Oertelt-Prigione, S., \& Seeland U. (2010). Sex and gender differences in myocardial hypertrophy and heart failure. Circ. J. 74 (7), 1265-1273.

5. Stangl, G.I., Weisse, K., \& Dinger, C. (2007) Homocysteine thiolactone-induced hyperhomocysteinemia does not alter concentrations of cholesterol and SREBP-2 target gene mRNAS in rats. Exp. Biol. Med. (Maywood) 232 (1), 81-87.

6. Melnyk, A.V. \& Pentiuk, O.O. (2009). Aktyvnist enzymiv syntezu hidrohen sulfidu $v$ nyrkakh shchuriv [Activity of hydrogen sulfide production enzymes in kidneys of rats]. Ukr. biokhim. zhurnal - Ukrainian Biochemical Journal, 81 (4), 12-22. [in Ukrainian].

7. Goldstein, J.L., Campbell, B.K., Gartler, S.M. (1972). Cystathionine synthase activity in human lymphocytes: induction by phytohemagglutinin. J. Clin. Invest, 51 (4), 1034-1037.

8. Chiang, P.K., \& Cantoni G.L. (1977). Activation of methionine for transmethylation. Purification of the Sadenosylmethionine synthetase of bakers' yeast and its separation into two forms. J. Biol. Chem., 252 (13), 45064513.
13. Restoring assembly and activity of cystathionine $\beta$-synthase mutants by ligands and chemical chaperones / J. Kopeck, J. Krijt, K. Rakov [et al.] // J. Inherit. Metab. Dis. -2011 . - 34, № 1. - P. 39-48.

14. Specific interaction of methionine adenosyltransferase with free radicals / M. A. Avila, F. J. Corrales, F. Ruiz [et al.] // Biofactors. - 1998. - 8, № 1-2. - P. 27-32.

15. Structure-Based Insights into the Role of the Cys-Tyr Crosslink and Inhibitor Recognition by Mammalian Cysteine Dioxygenase / C. M. Driggers, K. M. Kean, L. L. Hirschberger [et al.] // J. Mol. Biol. - 2016. - 428, № 20. - P. 3999-4012.

16. Sex-related differences in methionine metabolism and plasma homocysteine concentrations / N. K. Fukagawa, J. M. Martin, A. Wurthmann [et al.] // Am. J. Clin. Nutr. - 2000. - 72, № 1. - P. 22-29.

9. Stipanuk, M.H., De la Rosa J., \& Hirschberger, L.L. (1990). Catabolism of cyst(e)ine by rat renal cortical tubules. J. Nutr., 120 (5), 450-458.

10. Orlowski, M., \& Mrister A. (1971). Partial reaction by $\mathrm{y}$-glutamylcysteine synthetase and evidence for an activated glutamate intermediate. J. Biol. Chem. 246 (23), 7095-7105.

11. Gaitonde, M.K. (1967). A spectrophotometric method for direct determination of cysteine in the presence of other naturally occuring amino acid. Biochem. J., 104 (2), 627-633.

12. Zaichko, N.V., Pentiuk, N.O., Pentiuk, L.O., Melnyk, A.V., \& Andrushko, I.I. (2009). Vyznachennia vmistu hidrohen sulfidu v syrovattsi krovi [Determination of hydrogen sulfide in blood serum]. Visnyk naukovykh doslidzhen - Bulletin of Scientific Research, 1 (59), 29-32 [in Ukrainian].

13. Kopeck, J. Krijt, J., \& Rakov K. (2011). Restoring assembly and activity of cystathionine $\beta$-synthase mutants by ligands and chemical chaperones. J. Inherit. Metab. Dis. 34 (1), 39-48.

14. Avila, M.A., Corrales, F.J., \& Ruiz F. (1998). Specific interaction of methionine adenosyltransferase with free radicals. Biofactors, 8 (1-2), 27-32.

15. Driggers, C.M., Kean, K.M., \& Hirschberger L.L. (2016). Structure-Based Insights into the Role of the Cys-Tyr Crosslink and Inhibitor Recognition by Mammalian Cysteine Dioxygenase. J. Mol. Biol., 428 (20), 3999-4012.

16. Fukagawa, N.K., Martin, J.M., \& Wurthmann A. Sex-related differences in methionine metabolism and plasma homocysteine concentrations. Am. J. Clin. Nutr., 72 (1), 22-29. 


\section{ГЕНДЕРНЫЕ ОСОБЕННОСТИ ВЛИЯНИЯ ГИПЕРГОМОЦИСТЕИНЕМИИ НА МЕТАБОЛИЗМ СЕРОСОДЕРЖАЩИХ АМИНОКИСЛОТ И ГИДРОГЕН СУЛЬФИДА В ПЕЧЕНИ}

\section{Резюме}

Вступление. Нарушения обмена серосодержащих аминокислот являются признанными метаболическими фракторами риска кардиоваскулярной патологии. Однако остается неясным вопрос о их причастности к формированию пол-специфической патологии сердечно-сосудистой системы.

Цель исследования - изучить влияние длительной тиолактоновой гипергомоцистеинемии на содержание серосодержащих метаболитов в крови и активность энзимов обмена гомоцистеина, цистеина и гидроген сульфида в печени крыс обоего пола.

Методы исследования. Опыты проведены на 40 белых лабораторных крысах обоего пола массой 220-280 г. Модель длительной гипергомоцистеинемии создавали путем введения тиолактона D,L-гомоцистеина интрагастрально в дозе 100 мг/ка массы на 1 \% растворе крахмала 1 раз в сутки в течение 28 суток. В работе определяли содержание гомоцистеина, цистеина и гидроген сульфида в сыворотке крови, а также активность энзимов цистатионин-у-лиазы, цистатионин- $\beta$-синтазы, цистеинаминотрансфреразы, метионинаденозилтрансферазы, цистеиндиоксигеназы и у-глутамилцистеинлигазы в печени.

Результаты и обсуждение. Гипергомоцистеинемия инициировала пол-специсрические изменения содержания серосодержащих метаболитов в сыворотке крови крыс: возрастание содержания гомоцистеина и цистеина и снижение уровня гидроген сульфида составили, соответственно, 111; 59,2 и 59,4 \% у самцов, 82,4; 38,0 и 47,5 \% у самок $(p<0,05)$ по сравнению с контролем. В условиях гипергомоцистеинемии у самцов отмечали более отчетливое снижение в печени активности энзимов реметилирования и транссульфрурирования гомоцистеина (на 20,5-24,8 \% у самцов, на 13,4-15,4 \% у самок, р<0,05), энзимов деградации цистеина в окислительном и конъюгационном путях (на 21,1-22,0 \% у самцов, на 13,4-15,3 \% у самок, p<0,05), а также $\mathrm{H}_{2}$ S-продуцирующих энзимов (на 20,6-25,9 \% у самцов, на 13,5-17,5 \% у самок, р<0,05) по сравнению с контролем.

Выводы. Показано, что длительное введение тиолактона гомоцистеина сопровождается возрастанием содержания гомоцистеина, цистеина и уменьшением уровня гидроген сульфида в крови особей обоего пола, однако более существенные изменения отмечают у самцов. Наряду с этим регистрируют пол-специфрические изменения метаболизма серосодержащих соединений в печени: у самцов отмечают достоверно большее снижение активности фрерментов реметилирования и транссульфурирования гомоцистеина, энзимов деградации цистеина и синтеза гидроген сульфрда в печени по сравнению с самками крыс.

КЛЮЧЕВЫЕ СЛОВА: гомоцистеин; цистеин; гидроген сульфид; кровь; печень; энзимы.

\section{GENDER CHARACTERISTICS OF HYPERHOMOCYSTEINEMIA EFFECT ON METABOLISM OF SULFUR-CONTAINING AMINO ACIDS AND HYDROGEN SULFIDE IN LIVER}

\section{Summary}

Introduction. Sulfur amino acid disorders are recognized as metabolic risk factors for cardiovascular pathology. However, the question of the involvement of sulfur amino acids in the formation of the gender-defined pathology of cardiovascular system remains unclear.

The aim of the study - research the impact of thiolactone hyperhomocysteinemia (HHC) on blood levels of sulfur-containing metabolites and enzymes activity in metabolism of homocysteine, cysteine and hydrogen sulfide in the liver of rats of both sexes.

Methods of the research. Experiments were conducted on 40 white laboratory rats of both sexes weighing 220-280 g. Hyperhomocysteinemia was modeled by long-term intragastric administration of thiolactone D, L-ho- 
mocysteine, dosage $100 \mathrm{mg} / \mathrm{kg}$, in $1 \%$ starch solution once per day for 28 days. The research determines the content of homocysteine, cysteine and hydrogen sulfide in blood serum and activity of enzymes in the liver cystathionine- $y$-lyase, cystathionine- $\beta$-synthase, cysteine aminotransferase, methionine adenosyltransferase, cysteine dioxygenase and y-glutamylcysteine ligase.

Results and Discussion. Hyperhomocysteinemia initiates gender-defined changes in the content of sulfurcontaining metabolites in the serum of rats: increase homocysteine and cysteine and reduction of hydrogen sulfide is 111; 59.2 and $59.4 \%$ in males (females $-82.4,38.0$ and $47.5 \%, p<0.05$ ) respectively compared to the control group. HHC in males has led to a more distinct decreased in liver enzyme activity of homocysteine methylation and transsulfuration (on 20.5-24.8 \% in males and on 13.4-15.4\% in females, $p<0.05$ ), enzymes of cysteine degradation in oxidative and conjugation ways (in 21.1-22.0\% in males and on 13.4-15.3\% in females, $p<0.05$ ) and $\mathrm{H}_{2} \mathrm{~S}$-synthesizing enzymes (20.6-25.9\% in males and on $13.5-17.5 \%$ in females, $\left.p<0.05\right)$ compared to the control group.

Conclusions. It was shown, thiolactone homocysteine administration is accompanied by the rise of homocysteine, cysteine and the reduced levels of hydrogen sulfide in blood in individuals of both sexes, but more significant changes were observed in males. In addition, gender defined changes in the metabolism of sulfur-containing compounds in the liver were registered: male rats showed significantly greater decrease in liver enzyme activity of homocysteine remethylation and transsulfuration, cysteine degradation enzymes and synthesis of hydrogen sulfide in the liver compared to female rats.

KEY WORDS: homocysteine; cysteine; hydrogen sulfide; blood; liver enzymes.

Адреса для листування: А. В. Мельник, вул. Пирогова, 56, Вінниця, 21018, Україна, e-mail: anderneting@gmail.com. 